\title{
Opportunity to Teach: Push-In and Pull-Out Models of English
}

\section{Learner Instruction}

\author{
Laura Baecher ${ }^{1 *} \&$ Angela B. Bell ${ }^{2}$ \\ ${ }^{1}$ Department of Curriculum and Teaching, Hunter College, City University of New York, NY, USA \\ ${ }^{2}$ Department of School Leadership, Creighton University, Great Falls, MO, USA \\ *Laura Baecher, E-mail: lbaecher@hunter.cuny.edu
}

Received: March 21, 2017

Accepted: March 31, $2017 \quad$ Online Published: April 18, 2017

doi:10.22158/jecs.v1n1p53

URL: http://dx.doi.org/10.22158/jecs.v1n1p53

\begin{abstract}
As the number of US English Language Learners (ELLS) increases, elementary educators struggle to make decisions related to curriculum and instruction. This research fills an important gap in the research on program models for ELLs by presenting a two-part investigation of push-in and pull-out English Language Development (ELD) instruction from the vantage point of English as a Second Language (ESL) teachers. The first part of the investigation uses nationally administered surveys to capture the practices, beliefs, and challenges of ESL professionals working in these models. The second part highlights the concerns raised by those ESL teachers regarding the extent to which a cohort of 175 ELL students received their ELD instruction. We explore the implications for the academic achievement of ELLs in the primary grades when their access to consistent ELD instruction is curtailed. We illuminate the problematic aspects of both models and call for greater attention to the implementation and monitoring of services for young ELLs.
\end{abstract}

\section{Keywords}

English learners, language education, English as a Second Language, ESL program models, English Language Development

\section{Introduction}

The number of children who are learning English as an additional language in US schools is increasing faster than any other segment of the child population (Hernández, Denton, \& Macartney, 2007) and English Language Learners (ELLs) form the majority student population in all major US cities (Sable, Plotts, \& Mitchell, 2010). Although the federal government requires states to provide some type of programming to meet the needs of ELLs, this instruction varies across states, districts, and even within schools. Some states require a particular number of instructional minutes of targeted English Language Development (ELD) based on language proficiency, while others leave the specific time allocation up 
to schools. In elementary schools, these minutes are often provided by English as a Second Language (ESL) certified or endorsed teachers through push-in, pull-out, and co-teaching models of ELD, whose respective benefits have been debated (Saunders, Foorman, \& Carlson, 2006; Saunders, Goldenberg, \& Marcelletti, 2013). In U.S. elementary schools the most common ESL models are push-in and pull-out, in which ELD is provided by an ESL teacher who either removes students from the classroom or enters the mainstream classroom to provide ELD support. While sometimes push-in/pull-out instruction involves strong collaboration, with partnered ESL and classroom teachers routinely co-planning and co-teaching, we have found these situations are the exception rather than the norm (Bell \& Baecher, 2012). Push-in is often privileged as being a more "inclusive" model since the instruction ideally is provided by two teachers working collaboratively within the mainstream classroom, yet research on co-teaching models both from the field of special education and ESL has shown that such collaboration is very rare, as it is dependent on administrative support, interpersonal relationships, allocated time and resources, common expertise, and equal status (Friend \& Cook, 2010). As such, although push-in is perceived as more collaborative and inclusive than pull-out, both models operate according to similar constraints (Baecher \& Bell, 2011). In fact, when Saunders, Foorman and Carlson (2006) studied ELD provided as stand-alone instruction (pull-out) versus integrated (push-in), they found that ELLs made greater gains in the pull-out model, as the teacher could focus more exclusively on English language skills. When they tallied minutes spent in stand-alone ELD blocks, they found that $91 \%$ of the time was focused on reading and instructional activities in English, in contrast with 69\% in non-ELD block classrooms.

Still, there is likely value in judicious application of both push-in and pull-out models, as Fearon (2008) concluded in a year-long participatory investigation of elementary ESL and classroom teacher collaboration across both contexts. Fearon found that the quality and extent of collaboration between classroom and content teachers was more important than the program delivery model, and that both models provide unique learning opportunities for both ELLs and their teachers. Ultimately, targeted instruction of academic English as part of their school day (Goldenberg, 2013) is only made possible through institutional supports for ESL instructional time whatever the given model.

In this paper, rather than make a case for the superiority of a particular ELD model, we examined the “opportunity to learn” (Aguirre-Muñoz \& Amabisca, 2010) afforded elementary-level ELLs as provided through these models. We explored the day-to-day realities of push-in and pull-out instruction from the vantage point of ESL teachers across the US; hence, our framework is one of "opportunity to teach". As instructional providers, ESL teachers are best positioned to offer meaningful insight on the data we examined, leading to actions towards better practice. Like Heineke, Coleman, Ferrell and Kersemeier (2012), we believe that "educators who work directly with students are the most immediate advocates for bilingual pupils. A well-informed teacher-familiar with language policy guidelines and aware of the unique linguistic needs - can better advocate for classroom and program resources" ( $p$. 133). In addition, our experience as teacher educators and researchers engaged in collaborative inquiry 
with ESL elementary teachers has raised deep concerns about the manner in which push-in and pull-out instruction is being implemented within either under-resourced schools, or in schools with low populations of ELLs, as their teachers are often split between more than one building. In particular, the quality and amount of time actually provided to ELLs has been reported to us as being far less than what ESL teachers believe necessary to support their learners (Bell \& Baecher, 2012). In the same way that ELLs often lack opportunities to learn, ESL teachers are constrained by a lack of opportunities to teach or exercise their expertise in providing targeted ELD instruction to their ELLs. This constraint may stem from the erroneous belief that ESL is "just good teaching" and that ELD will occur without any focused instructional attention (Harper \& de Jong, 2009), in spite of clear evidence that shows that ELLs need targeted ELD in order to make proficiency gains (Saunders, Goldenberg, \& Marcelletti, 2013).

Like ESL teaching generally, push-in and pull-out instruction may be implemented interchangeably despite clear concerns expressed by both ESL and classroom teachers about these models' impact on ELLs. McClure and Cahnmann's (2010) study of push-in ESL teachers exposed their “self-perceptions of powerlessness...rather than being active participants in designing and selecting the pedagogical approaches they will carry out, the [ESL] teachers instead...are the puppets that will implement decisions made by those in positions of power" (p. 115). Our purpose, therefore, was to give voice to those with the deepest knowledge of these program models-ESL teachers themselves - enabling them to share their experiences, frustrations, and solutions to one of the greatest challenges currently facing US elementary schools: promoting the linguistic and academic success of children whose home language is not English. By reporting on the practices of push-in and pull-out ESL teachers, our aim was to fill an important and overlooked aspect in the literature on ELL instruction for at-risk youth and provide voice to ESL teachers who both participate and witness the implementation of these models. Research questions that motivated this study included:

1. To what extent do ELLs receive their allotted instructional minutes in either push-in or pull-out models?

2. What are the challenges and successes ESL teachers experience when serving students in push-in and pull-out models?

Both questions have urgency for the education of English learners in US schools, and have not been addressed in the research on childhood education.

\section{Method}

In order to closely examine push-in and pull-out ESL instruction, as well as to discover whether challenges inherent in these models were shared across a wide range of school settings, we designed a two-part study set to provide both fine and larger grain views of their implementation. Our research aims were to explore the ways push-in and pull-out models are implemented in terms of instructional minutes they afforded for ELD, the challenges/successes ESL teachers faced when working in these 
models, and the strategies they had developed to be more successful and strategic within these models.

\subsection{Research Procedures}

The first phase of the study began with a call to K-12 ESL teachers nationally, via postings to TESOL list-servs, to participate in an online questionnaire about their teaching model for ELLs and to describe how they collaborated with classroom and content teachers for the benefit of their ELL students. The design of the first phase of the study incorporated a cross-sectional internet survey to elicit respondents across a range of school contexts. A draft version of the online survey was piloted with 15 ESL teachers who completed the survey as well as provided feedback on format, content, and length before it was administered. We revised the instrument, with special consideration to issues of item design, following recommendations for the design of surveys by Dornyei (2003) and Babbie (1973). The survey included quantitative (forced-choice) and qualitative (open-ended) questions based on issues related to ESL program models and collaboration. Responses were then sorted to identify, from the 72 total participants, those who were ESL teachers in push-in and/or pull-out teaching models in grades K-5. Results of this questionnaire revealed participant teachers' strong concerns about the barriers ESL teachers encountered in providing their learners adequate instructional time within push-in and pull-out instruction. We, therefore, initiated the second phase of the study to examine the phenomena more closely and on a smaller scale.

For the second phase of the study, we sought K-5 ESL teachers who were willing to respond in greater detail about their students and teaching within push-in and/or pull-out teaching models. Recruitment was done by sending out an invitation to all those who had completed the questionnaire in phase one. Participant teachers had to agree to track the actual minutes of ELD provided to their caseload of ELLs for an entire month (March was chosen for having fewer US holiday breaks), provide information about those learners, explain the reasons why any instructional minutes were not provided, and follow up with responses to a questionnaire.

\subsection{Participants}

Out of the ESL teachers who participated in the first phase of the study, 46 self-identified as teaching in grades K-5. Participants in the first phase represented 16 states, from all regions of the US, and the District of Columbia. The number of ELLs they served ranged from 4 to 143 ELLs, with the average caseload of 43. All but three participants were certified ESL teachers, and their experience ranged from less than one year to more than eight years, with $70 \%$ having more than five years of ESL teaching experience. About half of the teachers (48\%) served their ELL students in pull-out, while 17\% pushed into classes, and 35\% used a combination of push-in and pull-out.

Thirty-two elementary ESL teachers out of the 46 in phase one agreed to participate in the second phase of the study. Of these 32, 20 were randomly selected, and from these 20, 9 persisted and completed the entire month of data tracking. During the second phase of the study, participants voluntarily tracked the instructional minutes provided to their ELLs, receiving no remuneration for this data collection. Due to the sensitive nature of the data these ESL teachers collected, and especially 
because of their concerns about repercussions from their school administration for sharing this information, participants de-identified data about their ELL students and their places of employment. Participants in the second phase taught in 6 of the 16 states seen in the first phase, and the majority also had more than five years of teaching experience. The numbers of ELLs served by this subset of nine teachers ranged from 5 to 33 ELLs. As found in the first phase of the study, approximately half of the second study's teachers (54\%) served their ELL students in pull-out, while 33\% pushed into classes, and $13 \%$ used a combination of push-in and pull-out.

\subsection{Data Collection and Analysis}

All of the participants in phase 2 were provided an Excel spreadsheet designed for consistent data collection. First, they were asked to create a pseudonym, numbering system, or use abbreviations for each student in their caseload, list these students and provide descriptive information such as home language, length of time in US schools, whether the students received special education services, and whether they were designated as having limited or interrupted formal education. The next step involved participant ESL teachers recording, for every day (except weekends) in the month of data collection, how many minutes of ELD they provided for each student listed on this data collection spreadsheet, and whether this was provided as pull-out or push-in instruction. For every instance mandated minutes were not provided, the teacher entered an explanation. One example appears in Table 1.

Table 1. Sample Data Collection Table for ESL Teacher Participants

\begin{tabular}{|c|c|c|c|c|c|c|c|c|c|c|}
\hline $\begin{array}{l}\text { Student First Name, Last } \\
\text { Initial ONLY-Or use a } \\
\text { coding system to give } \\
\text { just a number or letter to } \\
\text { represent each student }\end{array}$ & $\begin{array}{l}\text { First } \\
\text { language } \\
\text { of S }\end{array}$ & $\begin{array}{l}\text { Grade } \\
\text { of S }\end{array}$ & $\begin{array}{l}\text { \# years in } \\
\text { ESL in } \\
\text { US } \\
\text { schools }\end{array}$ & $\begin{array}{l}\text { Level of } \\
\text { English } \\
\text { proficiency: } \\
\text { Beginner } \\
\text { Intermediate } \\
\text { Advanced }\end{array}$ & $\begin{array}{l}\text { Number of } \\
\text { Instructional } \\
\text { Minutes in } \\
\text { ESL he/she } \\
\text { is entitled to } \\
\text { receive each } \\
\text { week }\end{array}$ & $\begin{array}{l}\text { IEP? } \\
\text { (yes or } \\
\text { no) }\end{array}$ & $\begin{array}{l}\text { SIFE? } \\
\text { (yes } \\
\text { or no) }\end{array}$ & $\begin{array}{l}\text { Instructional } \\
\text { Model in } \\
\text { which this } \\
\text { student } \\
\text { receives } \\
\text { his/her ESL } \\
\text { services (state } \\
\text { percentage) }\end{array}$ & $\begin{array}{l}\text { DATE PI or } \\
\text { PO? Minutes? } \\
\text { If not served, } \\
\text { reason why? }\end{array}$ & $\begin{array}{l}\text { DATE PI } \\
\text { or PO? } \\
\text { Minutes? } \\
\text { If not } \\
\text { served, } \\
\text { reason } \\
\text { why? }\end{array}$ \\
\hline Maria A. & Spanish & 5 th & 4 months & Beginner & 360 & No & Yes & $\begin{array}{l}P O-75 \% \\
P I-25 \%\end{array}$ & $\begin{array}{l}\text { PI-30 minutes } \\
\text { PO-30 } \\
\text { minutes }\end{array}$ & $\begin{array}{l}\text { No-I was } \\
\text { absent }\end{array}$ \\
\hline
\end{tabular}

Once the last day of the month had passed, participants were contacted by email and asked to reflect on their own data and respond in writing to the following prompt questions:

1. What did you personally notice or gain from collecting this data? Did you confirm anything you had suspected? Did anything surprise you?

2. What does your data make you think about instructional time that your ELLs are receiving (Beginners vs. Advanced students)?

3. How satisfied are you with the current amount and quality of instructional time you have with your ELLs?

Quantitative data that were generated in the online questionnaire and by participants tracking their ESL instructional minutes in the second phase of the study were analyzed in excel tables and simple descriptive tallies were performed. Range, median, mode and percentages were calculated and analyzed for trends and patterns related to the qualitative findings. For qualitative data generated in both 
studies - the open-ended responses to the questionnaire and participants' reflections on their logged instructional minutes - both authors independently interpreted the data, and then reviewed the analysis together. First, the qualitative responses were open-coded by looking for emerging themes while reading responses to each of the questions (Corbin \& Strauss, 2008). Many of the codes were in vivo codes that "capture the actual words used by participants" (Leech \& Onwuegbuzie, 2007, p. 576). Finally, the categories were selectively coded (Creswell, 2007) by rereading through all of the data to make sure the previous codes and categories were analyzed according to similarities and differences among participants and connected to emerging theory based on the principles of grounded theory (Glaser \& Strauss, 1967). We utilized synchronous and asynchronous online tools such as Google Docs and Skype as a means to reach consensus coding for all of the qualitative responses by reading through each other's analysis and discussing the interpretations.

\section{Result}

Qualitative data from the questionnaires in the first phase of the study and reflection on ELD service delivery provided by participants in the second phase of the study revealed a shared belief that push-in and pull-out models required more professional development to achieve than had been provided to them, more planning time to implement, and more collaborative relationships with co-teachers. They also strongly believed that ELLs were shortchanged in terms of the quality and extent of targeted ELD they received in both models. Quantitative data collected by participant teachers in the second phase of the study confirmed that ELLs were indeed receiving far fewer minutes of instructional time than was mandated — on average receiving only $50 \%$ of their entitled ELD periods.

\subsection{Concerns about Opportunity to Teach in Push-in and Pull-out Models}

In teachers' comments shared in phase 1 and 2 of the study, several common themes emerged, all of which pointed to barriers in providing ESL services to children.

(1) Lack of preparation to work in push-in or pull-out models. Many teachers commented that they had to learn to address the challenges of providing ESL instruction in push-in and pull-out models on the job. Many expressed frustration about the preparation for their roles received in their teacher preparation programs:

I am an equal with the classroom teachers in my school because I've fought for this status, but this subject is the elephant in the room...It deserves much more direct and concrete attention in teacher training, and I felt that the [teacher education] program did not sufficiently address the challenges and pitfalls of working alongside content teachers in a variety of models — especially push-in.

(2) Lack of common planning time. A commonly shared theme was the absence of formal planning time provided to the ESL and classroom teachers. One participant stated:

It is not fostered in a formal way...All co-planning efforts are done during individual teacher prep periods or outside of school. The administration expects teachers to co-plan, as well as come together and submit comprehensive unit plans per grade, but the actual lesson and unit planning work is done at 
the initiative of the teachers.

(3) Lack of status in the classroom. Another theme expressed was their sense that other teachers and therefore, students, did not see them as more than a classroom aide. In the words of one participant, "Kids think I'm not a real teacher". One participant expressed:

Many teachers in my school think that I'm a special education teacher. My current co-teacher treats (and probably sees) me as an equal, but one of the teachers I worked with last year treated me like a student. I have had several students tell me that I should be a teacher when I grow up. They see me as a "helper", or even an intern.

Some participants commented that this led to their students' reactions to them being in the room at times to be "negative" or to resist coming with them for pull-out instruction.

Another troubling aspect of feeling they were subordinate to classroom teachers was participants' feeling of being trapped into silence; when the classroom teacher did little advanced planning, the ESL teachers did not feel they could let an administrator know of this lack of preparation without fear of retaliation from the classroom teachers. When the classroom teachers did not plan, it made it impossible for the ESL teachers to supplement the lesson meaningfully, thus reducing their role again to a floating "helper".

(4) Lack of information exchange with classroom teacher. Another common concern across participants was the absence of regular communication with the classroom teacher about their shared ELL students. One participant stated: "I don't really know what's happening in the classroom and how the student is progressing. They don't seek info on what I do. I have to 'corner' them to get an update". Participants expressed a desire to bring in supporting materials, assist in scaffolding the content-area texts, and reinforce vocabulary related to the lesson, but they remarked that they "lacked control over the lessons" and therefore most often "floated" around the room. Many said they were overwhelmed with the number of different classroom teachers they worked with, thus negating the possibility of deep or consistent collaboration. Collaborating with "everybody" became collaboration with nobody.

(5) Lack of targeted ELD instruction. Another theme that was prevalent in the data was teachers' describing how, during push-in instruction, they felt they were unable to provide real English language instruction. One participant stated:

I am in the classroom the mandated number of minutes. Since I co-teach though, I am not always working with ELLs while in the room with them, and I feel that I do very little in the way of ESL instruction.

In addition, several ESL teachers indicated that they were frustrated by the amount of time they spent testing, which took away from instructional time. Teachers also wrote about cutbacks to resources impacting their ability to meet with their students, losing too much time during transition for the pull-out model, and having to compete with other services (such as special education, reading intervention, etc.) for time.

(6) Lack of physical space. A lack of physical space was another common theme in our data. When ESL 
teachers did not have a space to bring ELLs to provide pull-out instruction, they had no option but to push-in. One teacher stated, "No. I do not have time in my day to work with all the students. I do not have a classroom, and it is difficult to push-in to 34 classrooms in one day".

(7) Lack of teacher time to serve students in the caseload. One part-time teacher said there was "no way I could ever serve everyone with direct services" because she taught "about 143 children in 7 schools". One teacher served 75 ELLs in one school; in addition to having a difficult time serving all of her students, she realized that with transition time walking between the students' mainstream classroom and her pullout classroom, the students lost valuable instructional time. Participants lamented that having interrupted schedules due to testing, special events, and meetings added up to "weeks of lost instruction". Responses in the first phase of the study indicated that $28 \%$ of teachers believed they were with their students for the expected minutes. Twenty percent did not have mandated minutes. Fifty-two percent of the participants were not able to meet the mandated or expected minutes for teaching ELLs in their schools, and 8\% said they "sometimes" or "most of the time" met the minutes (when the "grade level teachers promptly send the students", and "when there are no special events...picture day, field day, assemblies, field trips, testing, or other schedule changes"). Testing seemed to be a dominant reason for not being able to schedule ESL instructional time. One teacher stated, "I am out for a month at the beginning of school and for two months at the end of school for testing! That's a lot of time to be away".

\subsection{Close Examination of Instructional Minutes}

In the second phase of the study, the push-in/pull-out elementary ESL teacher participants logged their daily instructional time with either all or one class of their ELLs for one month, reporting on 175 ESL students combine. These teachers ranged in the size of the caseload they reported on for this study and the models through which they provided ELD to their ELLs, as seen in Table 2. Four of the nine teachers provided instruction in a pull-out model, three in a combination of push-in and pull-out, and two provided ELD in a push-in model. The number of students they reported on ranged from 5 to 44 and their grades represented K-5 with most students being served in $3^{\text {rd }}$ and $4^{\text {th }}$ grade. English language proficiency levels of the ELLs these teachers served included 45 beginners (26\%), 28 intermediates (16\%), and 102 advanced ELLs (58\%). Pull-out only teaching took place for 95 out of the 175 students (54\%), push-in teaching for 58 (33\%), and combination push-in/pull-out was provided to 22 of the students (13\%) who teachers tracked for this study.

Table 2. Participant ESL Teacher Program Model and Caseload

\begin{tabular}{llll}
\hline Teacher* & Program Model & \# of ELLs in Caseload & \# of ELLs at beginner, intermediate and advanced levels \\
\hline \multirow{2}{*}{ Christy } & Pull-out & 30 & B-6 \\
& & & I-4 \\
& & & A-20 \\
Layla & Pull-out & 11 & B-0 \\
& & & I-0 \\
Sherryl & Pull-out & 25 & A-11 \\
\hline
\end{tabular}




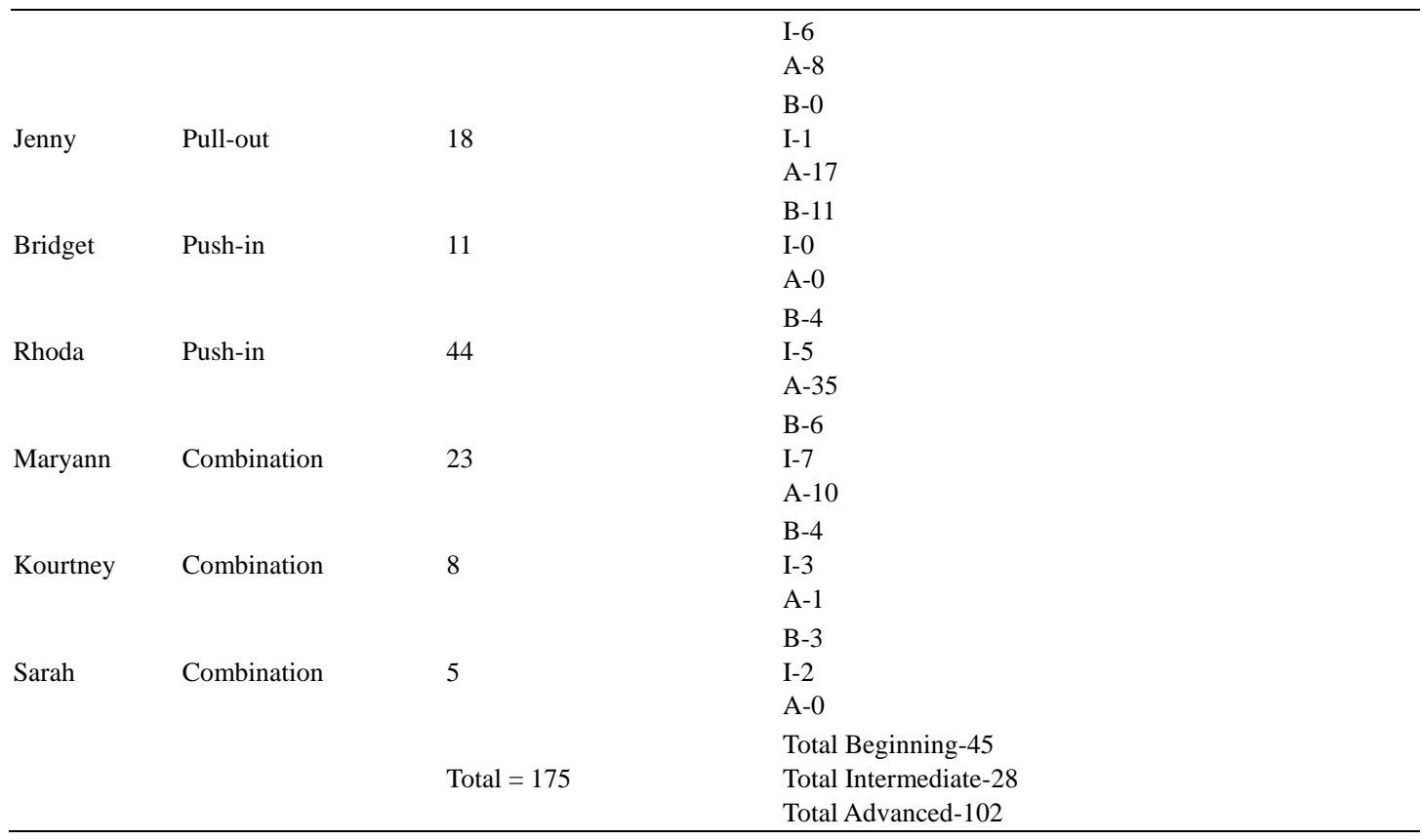

* All names are pseudonyms.

The students were predominantly Spanish speakers (57\%), followed distantly by Chinese (7\%), Korean (6\%), Arabic and Bengali (both 4\%) and 19 other languages represented in small numbers. Of the 175 students, 13 (7\%) were designated as students having limited or interrupted formal education and 33 (19\%) had Individualized Education Plans (IEPs) and received special education services. Almost all (97\%) were eligible for free or reduced lunch. The average time in the US for these students was 2 years and nine months.

The number of minutes mandated for ELLs across participant teachers varied, with the average being 180 minutes per week for advanced ELLs and 360 for beginner and intermediate ELLs. The actual number of minutes provided to ELLs was examined in a number of ways. In Table 3 the minutes to which ELLs were entitled are aggregated across the participant teachers.

Table 3. Instructional Minutes Provided in One Month of Data Tracking

\begin{tabular}{lllll}
\hline Week & $\begin{array}{l}\% \text { of PI } \\
\text { minutes } \\
\text { provided }\end{array}$ & $\begin{array}{l}\% \text { of PO } \\
\text { minutes } \\
\text { provided }\end{array}$ & $\begin{array}{l}\text { \% of CMBO } \\
\text { Minutes } \\
\text { Provided }\end{array}$ & $\begin{array}{l}\text { \% of Total Push-in, Pull-out and Combination } \\
\text { minutes (PI+PO+CMBO) provided out of Total } \\
\text { Entitled Minutes }\end{array}$ \\
\hline 1 & $57 \%$ & $61 \%$ & $51 \%$ & $58 \%$ \\
2 & $19 \%$ & $67 \%$ & $55 \%$ & $53 \%$ \\
3 & $29 \%$ & $34 \%$ & $80 \%$ & $41 \%$ \\
4 & $51 \%$ & $70 \%$ & $77 \%$ & $67 \%$ \\
Average \% Provided & $39 \%$ & $58 \%$ & $66 \%$ & $55 \%$ \\
\hline
\end{tabular}

A week-by-week overview shows that out of a possible 38,405 minutes of ELD instruction that were intended to be provided to the 175 ELLs in the study, an average of $50 \%$ were actually provided in weeks one, two and four. In the third week of the month studied, 40\% of ELD instructional minutes were provided due to field-testing of new state tests, field trips, and parent-teacher conference days. 
Examination of instructional minutes by program model shows that ELLs in push-in instruction received only about $40 \%$ of their required minutes, those in pull-out received about $60 \%$, and those receiving ESL services in a combination of both received about $65 \%$ of theirs. When instructional minutes provided by teacher participant were examined, the percentage of time where provided instructional minutes equaled or exceeded students' entitled minutes ranged from zero to $57 \%$ across the nine ESL teacher participants, with an average of $20 \%$. Teachers who taught in both push-in and pull-out (combination), or pull-out were more likely to successfully provide instruction than teachers working exclusively in push-in instruction.

Participants identified a reason for each set of minutes that were not provided. These reasons included, in order of least to most frequent (1) teacher absence, (2) classroom teacher holding the student in class to continue work, (3) professional development days, (4) student absence, (5) re-assignment to serve as a substitute teacher for the day, (6) screening new entrants or attending to ESL compliance work, or (7) state testing. Testing appeared in this month of data collection to be the most common reason for teachers to be unable to provide services. While it would seem logical that caseload might influence the ESL teacher's ability to provide instructional minutes, that was not the case in our data. Teachers with fewer and greater numbers of ELLs to serve were equally likely to provide instructional minutes, with no participant exceeding $57 \%$ of mandated minutes.

After the data collection phase ended, participant teachers were asked to reflect on their data and share observations. In addition to strongly re-iterating the themes which emerged in the first phase of the study, participants expressed deep concern about the time of targeted ELD they were providing to their ELLs, and wondered if their ELLs would ever be able to make significant gains in their English skills, due to the lack of services. One teacher stated, "I think the limited services impact the progress of the lowest level students and may lead to long-term ELL status". Another teacher sums it up:

I feel the quality of the time is good, in that much can be accomplished in a 30-45 minute class; however, the quantity of services is poor because of frequent interruptions (assessing new entrants, state testing, classroom events). At certain times of the year, I don't see some students for an entire week and that can happen multiple times for some students...My data makes me think that every moment is important so I need to utilize every moment as constructively as possible.

\section{Discussion}

Our results suggest that in some schools, there is urgent need for attention to ELLs' access to developing English language skills. In our study, many pull-out ELL teachers appeared frustrated with their current teaching circumstances as they often do not have the opportunity to meet with their students for the appropriate amount of time. However, teachers who are working in a push-in model, or a combination of both models, also have frustrations and do not feel they are able to adequately serve their students based on the barriers to collaboration. Although an English learner's success cannot be quantified by the number of minutes an ESL teacher works with him/her, it is important to recognize 
that ESL teachers are often frustrated when they feel they are not able to sufficiently meet the needs of their students, especially where they continue to simultaneously feel that the sole responsibility for educating English learners is theirs.

This study has implications for policy makers, teacher educators, and school leaders. Although most principals would likely assert that they wish to see their ELL populations progress academically, the majority in our studies made decisions that had the opposite effect. Research on principals shows the continued need for more learning about ELLs. While school leaders nationwide are concerned about how to support ELLs' development and learning, many find this role especially challenging, for many can draw neither upon personal experience (Grosland, Gund, \& Horsford, 2011; Lohfink, Morales, Shroyer, \& Yahnke, 2012), nor professional preparation in the instruction of linguistically diverse students (Buysse, Castro, West, \& Skinner, 2005; Gándara, Maxwell-Jolly, \& Driscoll, 2005; Landa, 2011; Reyes, 2006; Suttmiller \& González, 2006). Yet examples are emerging of how school leadership can make a tremendously positive impact on ELLs. For instance, Theoharis and O'Toole (2011) describe two highly successful school reform initiatives that required ESL and content teachers to work closely together. Although in one school this involved teachers in acquiring dual licenses (ESL and elementary generalist), in the other it took the form of supporting inclusive teaching models. Both schools had principals who were highly motivated and committed to the success of ELLs in their buildings. Positive and negative examples of opportunity to learn for ELLs suggest that the level of regard given by classroom teachers and school administrators to the professional knowledge and status of ESL teachers affects their ability to secure consistent and meaningful instructional time with the ELLs in their caseload of ELLs. Some of the ways school leaders and teachers could work together in their school sites to investigate the implementation of the instructional program at their site might involve posing these questions and encouraging honest reflection on the answers they receive:

- Who considers themselves "responsible" for ELD instruction at the school? Are ESL students' schedules true schedules or only for show? Are the mandated minutes actually incorporated into their weekly schedule?

- How often are ESL teachers asked to serve as substitutes for absent colleagues and abandon their instructional program? When they are absent, does anyone cover for them?

- How many classroom teachers is one ESL teacher supposed to coordinate with? Do the teachers co-plan to meet the needs of their learners by creating common goals? Do the teachers know what each other is accomplishing and what each others' goals are?

- If ESL teachers pull out, where do they go and how far do they have to travel?

Sharing specific strategies may be particularly helpful to school leaders, including: creating a master schedule in which ELLs are a priority; focusing on teacher workloads to ensure their caseload is manageable; seeking advice from the ESL teacher while making planning decisions; and creating and supporting a common planning time for educators to create common goals based on the needs of their learners and to plan for instruction based on those goals.

Published by SCHOLINK INC. 
Our research sought to illuminate ESL teachers' practices as well as their concerns about meeting the needs of their English learners. Our findings suggest that ESL teachers may not have adequate time to work with their students for various reasons. If debates about instructional model are set aside, more energy and attention can be paid to designing locally meaningful services that can truly and faithfully be delivered to young ELLs. In order for the next generation of ELL students to achieve, they need an opportunity to learn, and this means ESL teachers need the opportunity to teach.

\section{References}

Abdallah, J. (2009). Benefits of co-teaching for ESL classrooms. Academic Leadership the Online Journal, $7(1)$.

Aguirre-Muñoz, Z., \& Amabisca, A. (2010). Defining opportunity to learn for English language learners: Linguistic and cultural dimensions of ELLs' instructional contexts. Journal of Education for Students Placed at Risk (JESPAR), 15(3), 259-278.

Arkoudis, S. (2000). "I have linguistic aims and linguistic content": ESL and science teachers planning together. Prospect, 15(1), 61-71.

Arkoudis, S. (2006). Negotiating the rough ground between ESL and mainstream teachers. The International Journal of Bilingual Education, 9(4), 415-433. https://doi.org/10.2167/beb337.0

Babbie, E. R. (1973). Survey research methods. Belmont, CA: Wadsworth.

Baecher, L., \& Bell, A. (2011). A "Continuum" model of collaboration in ESL. Academic Exchange Quarterly, 15(1), 56-61.

Bell, A., \& Baecher, L. (2012). Points on a continuum: ESL teachers reporting on collaboration. TESOL Journal, Special Issue on Teacher Collaboration in TESOL, 3(3), 488-515. https://doi.org/10.1002/tesj.28

Buysse, V., Castro, D. C., West, T., \& Skinner, M. (2005). Addressing the needs of Latino children: A national survey of state administrators of early childhood programs. Early Childhood Research Quarterly, 20(2), 146-163. https://doi.org/10.1016/j.ecresq.2005.04.005

Cheung, A., \& Slavin, R. E. (2012). Effective reading programs for Spanish dominant English Language Learners (ELLs) in the elementary grades: A synthesis of research. Review of Educational Research, 82(4), 351-395. https://doi.org/10.3102/0034654312465472

Corbin, J., \& Strauss, A. (2008). Basics of qualitative research (3rd ed.). Los Angeles, CA: Sage Publications.

Creese, A. (2002). The discursive construction of power in teacher partnerships: Language and subject specialists in mainstream schools. TESOL Quarterly, 36(4), 597-616. https://doi.org/10.2307/3588242

Creese, A. (2005). Teacher collaboration and talk in multilingual classrooms. Clevedon: Multilingual Matters.

Creese, A. (2006). Supporting talk? Partnership teachers in classroom interaction. International Journal Published by SCHOLINK INC. 
of Bilingual Education \& Bilingualism, 9(4), 434-453. https://doi.org/10.2167/beb340.0

Creswell, J. W. (2007). Qualitative inquiry and research design: Choosing among five approaches (2nd ed.). Thousand Oaks, CA: Sage.

Cutri, R., \& Johnson, C. (2010). Overcoming deficit thinking toward English Language Learners: Technological possibilities. Teacher Education Quarterly. Retrieved from http://www.teqjournal.org/cutri_johnson.html

Davison, C. (2006). Collaboration between ESL and content teachers: How do we know when we are getting it right? International Journal of Bilingual Education, 9, 454-475.

Díaz-Rico, L., \& Weed, K. (2006). The cross-cultural, language, and academic development handbook: A complete K-12 reference guide (3rd ed.). Boston: Allyn \& Bacon.

Dornyei, Z. (2003). Questionnaires in second language research: Construction, administration and processing. Mahwah, NJ: Lawrence Erlbaum.

Dove, M., \& Honigsfeld, A. (2010). ESL coteaching and collaboration: Opportunities to develop teacher leadership and enhance student learning. TESOL Journal, 1(1), 3-22. https://doi.org/10.5054/tj.2010.214879

Dove, M., \& Honigsfeld, A. (Eds.). (2012). Coteaching and other collaborative Practices in the EFL/ESL classroom: Rationale, research, reflections, and recommendations. Charlotte, NC: Information Age Publisher.

Drangsholt, L., Ignacz, J.. Porter, H., \& Sayler, L. (2012, November). A pathway to excellence and equity for all: Cherry Creek Schools. Paper presented at Colorado Teachers of English to Speakers of Other Languages Annual Conference, Denver, CO.

Echevarria, J., Vogt, M. E., \& Short, D. (2008). Making content comprehensible for English language learners: The SIOP model (3rd ed.). Boston: Allyn \& Bacon.

English, B. (2009). Who is responsible for educating English language learners? Discursive construction of roles and responsibilities in an inquiry community? Language and Education, 23(6), 487-507. https://doi.org/10.1080/09500780902954216

Faltis, C., Arias, M. B., \& Ramírez-Marín, F. (2010). Identifying relevant competencies for secondary teachers of English learners. Bilingual Research Journal, 33(3), 307-328.

Fearon, K. (2008). A team teaching approach to ESL: An evaluative case study (Masters Thesis). Kean University, Union, NJ.

Friend, M. (2008). Co-teaching: A simple solution that isn't simple after all. Journal of Curriculum and Instruction, 2(2), 9-19. https://doi.org/10.3776/joci.2008.v2n2p9-19

Friend, M., \& Cook, L. (2010). Interactions: Collaboration skills for school professionals (6th ed.). Boston: Allyn \& Bacon.

Gándara, P., Maxwell-Jolly, J., \& Driscoll, A. (2005). Listening to teachers of English language learners: A survey of California teachers' challenges, experiences, and professional development needs. Santa Cruz, CA: Center for the Future of Teaching and Learning. 
Genesee, F., Lindholm-Leary, K., Saunders, W., \& Christian, D. (2006). Educating English language learners. NY: Cambridge University Press.

Genesee, F., Lindholm-Leary, K., Saunders, W., \& Christian, D. (2005). English language learners in United States schools: An overview of research findings. Journal of Education for Students Placed at Risk, 10(4), 363-385. https://doi.org/10.1207/s15327671espr1004_2

Gibson, M. A. (1988). Accommodation without assimilation. Ithaca, NY: Cornell University Press.

Glaser, B., \& Strauss, A. (1967). The discovery of grounded theory. Chicago: Aldine.

Goldenberg, C. (2008). Teaching English language learners: What the research does-and does not-say. American Educator, Summer, 8-44.

Gottlieb, M. (2006). Assessing English Language Learners: Bridges from language proficiency to academic achievement. Thousand Oaks, CA: Corwin Press.

Grosland, T., Gund, K. M., \& Horsford, S. D. (2011). Pedagogy of the personal and professional: toward a framework for culturally relevant leadership. Journal of School Leadership, 21(4).

Hargreaves, A. (1994). Changing teachers, changing times: Teachers' work and culture in the post-modern age. New York: Teachers College Press.

Harklau, L. (1999). The ESL learning environment in secondary school. In C. J. Faltis, \& P. Wolfe (Eds.), So much to say: Adolescents, bilingualism, and ESL in the secondary school (pp. 42-60). New York: Teachers College Press.

Harper, C. A., \& de Jong, E. J. (2009). English language teacher expertise: The elephant in the room. Language and Education, 23(2), 137-151. https://doi.org/10.1080/09500780802152788

Harper, C., \& De Jong, E. (2010). Is ESL just good teaching? In M. Bigelow, \& C. Walker (Eds.), Creating teacher community: Selected papers from the third international conference on language teaching (pp. 115-132). Minneapolis, MN: University of Minnesota, Center for Advanced Research on Language Acquisition. Retrieved from http://www.carla.umn.edu/resources/working-papers/

Heineke, A. J., Coleman, E., Ferrell, E., \& Kersemeier, C. (2012). Opening doors for bilingual students: Recommendations for building linguistically responsive schools. Improving Schools, 15(2), 130-147. https://doi.org/10.1177/1365480212450235

Hernández, D. J., Denton, N. A., \& Macartney, S. E. (1999). Young Hispanic children in the 21st century. Journal of Latinos and Education, 6(3), 209-228. https://doi.org/10.1080/15348430701312859

Herrity, V. A., \& Glasman, N. S. (2007). Training administrators for culturally and linguistically diverse school populations: Opinions of expert practitioners. Journal of School Leadership, 9(3), 235-253.

Hess, F. M., \& Kelly, A. P. (2005). Textbook leadership? An analysis of leading books used in principal preparation. Cambridge, MA: Harvard University, Program on Educational Policy and Governance.

Hess, F. M., \& Kelly, A. P. (2007). Learning to lead: What gets taught in principal-preparation 
programs. Teachers College Record, 109(1), 244-274.

Hite, C., \& Evans, L. (2006). Mainstream first-grade teachers' understanding of strategies for accommodating the needs of English language learners. Teacher Education Quarterly, 33, 99-104.

Hoffman, P., \& Dahlman, A. (2007). Together we are better. Essential Teacher, 4(3).

Holcomb, E. L. (2009). Asking the right questions: Tools for collaboration and school change. Thousand Oaks, CA: Corwin Press.

Honigsfeld, A. (2009, Summer). ELL Programs: Not “One Size Fits All”. Kappa Delta Pi Record, 166-171. https://doi.org/10.1080/00228958.2009.10516539

Honigsfeld, A., \& Dove, M. (2008). Co-teaching in the ESL classroom. Delta Kappa Gamma Bulletin, $74(2), 8-14$

Honigsfeld, A., \& Dove, M. G. (2010). Collaboration and co-teaching: Strategies for English learners. Thousand Oaks, CA: Corwin.

Landa, C. (2011). Cultural proficiency in education: A review of the literature focused on teachers, school leaders, and schools. Gastón Institute Publications. Retrieved from http://www.scholarworks.umb.edu/gaston_pubs/143

Leech, N. L., \& Onwuegbuzie, A. J. (2007). An array of qualitative data analysis tools: A call for data analysis triangulation. School Psychology Quarterly, 22(4), 557-584.

Leung, C., \& Creese, A. (2010). English as an additional language: Approaches to teaching linguistic minority students. London: Sage.

Lohfink, G., Morales, A., Shroyer, G., \& Yahnke. S. (2012). Growing effective CLD teachers for today's classrooms of CLD children. Action in Teacher Education, 34(1), 41-54. https://doi.org/10.1080/01626620.2012.642287

Lucas, T., \& Villegas, A. M. (2011). A framework for preparing linguistically responsive teachers. In T. Lucas (Ed.), Teacher preparation for linguistically diverse classrooms (pp. 55-72). New York, NY: Routledge.

McClure, G., \& Cahnmann-Taylor, M. (2010). Pushing back against push-in: ESOL teacher resistance and the complexities of coteaching. TESOL Journal, 1(1), 101-129. https://doi.org/10.5054/tj.2010.214883

Murawski, W. W., \& Dieker, L. A. (2004). Tips and strategies for co-teaching at the secondary level. Teaching Exceptional Children, 30(5), 52-58. https://doi.org/10.1177/004005990403600507

Olsen, L. (2008). Made in America: Immigrant students in our public schools. New York: New Press.

Reeves, J. (2006). Secondary teacher attitudes toward including English-language learners in mainstream classrooms. The Journal of Educational Research, 99(3). https://doi.org/10.3200/JOER.99.3.131-143

Reyes, A. (2006). Reculturing principals as leaders for cultural and linguistic diversity. In K. Téllez, \& H. C. Waxman (Eds.), Preparing quality educators for English language learners: Research, policies, and practices (pp. 145-165). Mahwah, NJ: Lawrence Erlbaum.

Published by SCHOLINK INC. 
Ruiz-de-Velasco, J., Fix, M., \& Clewell, B. (2000). Overlooked and underserved: Immigrant students in US secondary schools. Retrieved from http://www.urban.org/publications/310022.html

Sable, J., Plotts, C., \& Mitchell, L. (2010). Characteristics of the 100 largest public elementary and secondary school districts in the United States: 2008-2009. Washington, DC: U.S. Department of Education. Retrieved from http://www.nces.ed.gov/pubs2011/2011301.pdf

Saunders, W., Foorman, B., \& Carlson, C. (2006). Is a separate block of time for loral English language development in programs for English Learners needed? The Elementary School Journal, 107(2), 181-198. https://doi.org/10.1086/510654

Saunders, W., Goldenberg, C., \& Marcelletti, D. (2013). English language development. American Educator, 13.

Scruggs, T. E., Mastropieri, M. A., \& McDuffie, K. A. (2007). Co-teaching in inclusive classrooms: A metasynthesis of qualitative research. Exceptional Children, 73, 392-416. https://doi.org/10.1177/001440290707300401

Slama, R. B. (2012). A longitudinal analysis of academic English proficiency outcomes for adolescent English language learners in the United States. Journal of Educational Psychology, 104(2), 265-285. https://doi.org/10.1037/a0025861

Suttmiller, E. F., \& González, M. L. (2006). Successful school leadership for English language learners. In K. Téllez, \& H. C. Waxman (Eds.), Preparing quality educators for English language learners: Research, policies, and practices (pp. 167-188). Mahwah, NJ: Lawrence Erlbaum.

Theoharis, G. (2007, November). Cases of inclusive ELL services: New directions for social justice leadership. Paper presented at the 2007 UCEA Conference, Washington, DC. Retrieved from http://www.coe.ksu.edu/ucea/2007/Theoharis3_UCEA2007.pdf

Theoharis, G. (2009). The school leaders our children deserve: Seven keys to equity, social justice, and school reform. New York: Teachers College Press.

Theoharis, G., \& O’Toole, J. (2011). Leading inclusive ELL: Social justice leadership for English language learners. Educational Administration Quarterly, 47(4), 646-688.

Thomas, W. P., \& Collier, V. (1997). School effectiveness for language minority students. NCBE Resource Collection Series.

Verplaetse, L. (1998). How content teachers interact with English language learners. TESOL Journal, $7(5), 24-28$

Walker, A., Shafer, J., \& Iiams, M. (2004). "Not in my classroom": Teacher attitudes towards English language learners in the mainstream classroom. NABE Journal of Research and Practice, 2(1), $130-160$

Walther-Thomas, C. S. (1997). Co-teaching experiences: The benefits and problems that teachers and principals report over time. Journal of Learning Disabilities, 30, 395-407.

Youngs, C., \& Youngs, G. (2001). Predictors of mainstream teachers' attitudes toward ESL students. TESOL Quarterly, 35(1), 97-118. https://doi.org/10.2307/3587861 